\title{
Management of Higher Education in the Accreditation of Study Programs at Bina Bangsa Getsempena College of Teacher Training and Education of Banda Aceh Indonesia
}

\author{
M. Najib \\ Coordinator of Private Higher Education \\ (Kopertis) Aceh, Indonesia \\ yusrizal_fkipunsyiah@yahoo.co.id
}

\author{
Yusrizal \\ Department of Educational Administration \\ Syiah Kuala University, Indonesia \\ yusrizal_fkipunsyiah@yahoo.co.id
}

\author{
Niswanto \\ Department of Educational Administration \\ Syiah Kuala University, Indonesia \\ yusrizal_fkipunsyiah@yahoo.co.id
}

\begin{abstract}
The purpose of this study is: to find out the management of the institution in the process of accreditation of study program at Bina Bangsa Getsempena College of Teacher Training and Education of Banda Aceh. This research uses qualitative approach with descriptive method. Data collection techniques are: interview and documentation study. Data analysis techniques with data reduction, data display, drawing conclusions and verification. The subjects of this study are Chairperson, Vice Chairperson, Heads of Bureau, Heads of Division, Heads of Bodies and Institutions, Bureaucracy Staff, Lecturers and Students. Based on the results of the research, it is found that: (1) The management of higher education conducted by Getsempena College of Teacher Training and Education of Banda Aceh is in accordance with the plan which has been prepared in the accreditation process of the study program. The planning involves all the elements in the organization so that everything is covered; (2) The programs in the process of accreditation of the study program are done in line with their respective duties and functions as stated in the decree of the accreditation team of the study program by the Head of Getsempena College of Teacher Training and Education of, it is seen the allocation of tasks in filling out accreditation form such as filling out the document of self-evaluation, accreditation document of study program and institutional document which comprise of seven accreditation standard; (3) The supervision of the accreditation process at Getsempena College of Teacher Training and Education of Banda Aceh is carried out by the Quality Assurance Agency and internal auditors that is conducted every six months concerning the progress of the preparation of accreditation covering seven accreditation standards.
\end{abstract}

Keywords: educational management, higher education, accreditation

\section{INTRODUCTION}

One of the factors that one chooses a study program is the calibre of the study program. The quality of a study program can be seen through the accreditation of the study program. Accredited study programs will produce high-quality graduates and have almost no difficulty in getting a job. The legality of study programs is an important aspect to pay attention to by all elements of institutions of higher education which consist of organizing bodies, university rectors, officials, lecturers and education personnel in every university. The status of accreditation reflects the quality of the institutions of higher education, from the aspect of commitment of study program towards institutional capacity and effectiveness of education programs.

The quality of the management of the study program in accreditation can be seen in standards as a benchmark that ought to be met by the institution and study programs which involves several parameters or performance indicators relating to seven groups of elements, namely: (1) vision, mission, goals and objectives, and achievement strategies; (2) leadership governance, management systems and quality assurance; (3) students and graduates; (4) human resources; (5) curriculum, learning, and academic atmosphere; (6) financing, facilities and infrastructure, and information systems; and (7) research, service/community service, and cooperation (National Accreditation Board for Higher Education, 2013).

\section{METHODS}

Based on the problems of this study that highlights the problems on management of the college in the accreditation process of study program at Bina Bangsa Getsempena College of Teacher Training and Education of Banda Aceh. This research employs qualitative approach. Through this research, it is expected that information can be exposed. Qualitative research is a research approach that expresses certain social situations by describing the reality correctly, formed by words based on the techniques of collecting and analysing relevant data obtained from natural situations (Satori and Komariah, 2010). This study uses descriptive method with a qualitative approach.

This refers to the formulation of a research problem that requires the researcher to carry out exploration in understanding and explaining the focus of the research question, namely on Management of Higher Education on the Accreditation Process of Study Program at Bina Bangsa Getsempena College of Teacher Training and Education of Banda Aceh. The design is provisional, but on an ongoing basis that is relevant to the reality in the field. Moreover, it does not 
use designs that have been rigorously and rigidly arranged which will make it impossible to change.

\section{RESULTS}

Preparation of Planning in the Accreditation Process of Study Program at Bina Bangsa Getsempena College of Teacher Training and Education of Banda Aceh

Initially, the chairperson/leader invited all lecturers, board officials, staff, students, alumni ties in the program preparation meeting. The manager of Bina Bangsa College of Teacher Training and Education of Banda Aceh must carry out education in accordance with its vision, namely to Become Higher Education for Teacher Education, independence, religiousness, and competitiveness in Southeast Asian region in 2033.

To achieve this vision, of course the program plan must be prepared by preparing program planning in the accreditation process of study program to be even better. Planning in management is the first step in mobilizing various resources within the framework to achieve organizational goals, so that planning can provide an overview of a goal to be achieved collectively.

Program Implementation in the Accreditation Process of Study Program at Bina Bangsa Getsempena Teacher Training College of Banda Aceh

The implementation process in management is an important course that shows the ability of the organization to empower all the resources it has so that an organizational performance, as well as individual performance, can be achieved. The implementation of a program that has been planned properly and carried out by the right team will easily achieve the goals. In the implementation of the accreditation process at BBG Teacher Training College has already had visions, missions, goals, and objectives that are arranged very clearly, realistically and have a relationship between each other by involving all stakeholders.

The vision of BBG Teacher Training College is to become an excellent teacher training, be independent and religious and competitive in the Southeast Asian region in 2033. Furthermore, the mission that must be carried out are: (1) organizing professional education that is excellent and qualified for teachers in accordance with the field of science and expertise; (2) cultivating a culture of conducting research and publishing the research results for education as an effort to improve competitiveness in social life; (3) administering a community service independently based on the needs of the community; (4) enhancing professional capacity of institution through collaboration with all stakeholders; and (5) applying and respecting religious values in developing education, research and community service.

In an effort to implement the freedom of the academic pulpit, each study program was given an autonomy to develop the scientific field as an effort to improve the ability to develop skills and scientific competitiveness. This was done by the publication of a journal related to the knowledge developed at $\mathrm{BBG}$ Teacher Training College.

Program Supervision in the Accreditation Process of Study Program at Bina Bangsa Getsempena Teacher Training College of Banda Aceh

Supervision as the final process of management is an activity that ensures whether the plans that have been prepared previously have been running as they planned. Good supervision is monitoring the beginning of activities and sustainability until the end of an activity.

The data and information obtained are based on these instruments which then are analysed by the AIMA team until the findings and results were obtained. Discussion of the findings was carried out by the AIMA Team together with the auditor to verify and to get responses and follow-up commitments from the auditor. Furthermore, the AIMA team reported the results to the chairperson of the BBG Teacher Training College in the form of the AIMA report to be further disseminated during an internal meeting at BBG Teacher Training College.

\section{DISCUSSION}

Private Institutions of Higher Education in Aceh continues to grow and spread across all regencies or cities in Aceh. Like it or not, every further education college should be able to compete and cope with the increasing establishment, shape shifting and the opening of new study programs. Currently, there are 109 private institution of higher education, 330 study programs that compete both in quality and quantity especially with the issue of the Southeast Asian Economic Community. The challenges to the private colleges in the global era are marked by the development of information and technology (IT). There are seems to be no boundaries between countries, as in the future foreign countries can found universities in Indonesia.

This indicates that the competition faced by private universities or institutions of higher education in Aceh is becoming increasingly complex, in addition to this problem with the Law Number 12 of 2012 concerning Higher Education and other Ministerial Regulations that are constantly changing in line with developments, so that it is demanded from the management of private institutions of higher education to go as expected. Based on the applicable legislation, organizers and lecturers should follow these developments where the excellence of study program accreditation has not been seen due to the weak management of universities in managing and implementing the Assurance System of Internal Quality. The sluggishness in implementing audit on education quality at Bina Bangsa Getsempena College of Teacher Training and Education of Banda Aceh has hampered the audit of the education quality of their own. In addition, the lack of auditors' training for assurance system of internal quality in every private higher institution that has an impact on the level of study program accreditation. 
The quality standard of higher education is something that cannot be ignored by higher education administrator. This is stipulated in Government Regulation Number 44 of 2015 concerning National Standards of Higher Education, in addition to various challenges of higher education include: (1) effect of global intervention and education liberalization; (2) national macro problems such as economic crisis, cultural moral politics; (3) the role of higher education in creating a decent civil society; and (4) the low quality of local/national graduates. The government continues to encourage higher education managers to keep improving the quality of higher education. In connection with these issues, the government has issued various laws and regulations which in principle encourage the improvement of the quality of education in Indonesia.

The Law on National Education System Number 20 of 2003 states that the control and evaluation of the quality of education must be carried out, both towards study programs and educational institutions on an ongoing basis. Likewise, under the Government Regulation Number 19 of 2005, it was affirmed that the establishment of national education standards is to realize the quality national education. Comprehensive success in keeping with the Strategic Plan of Ministry of Research, Technology and Higher Education 2014-2019 concludes that the determination of quality management in higher education is a necessity which ultimately leads to the ranking of higher education accreditation. Seeing the implementation of quality assurance of higher education to date, not all institutions of higher education understand it because the lack of knowledge to develop a quality assurance of higher education system in their respective institutions.

\section{CONCLUSION}

Management of higher education carried out by Getsempena Teacher Training College of Banda Aceh is in accordance with the plan that has been prepared in the accreditation process of study program. The planning involves all elements in the organization so that all the problems can be covered. Program implementation in the accreditation process of study program is carried out in relation to their respective functions as stated in the Decree of the study program accreditation team by the Chairperson of BBG Teacher Training College. This shows the distribution of tasks in filling out accreditation forms, namely filling out self-evaluation documents, accreditation book of study program and institution document books contained in seven accreditation standards.

Supervision of the accreditation process BBG Teacher Training College of Banda Aceh is carried out by the Quality Assurance Agency and internal auditors that are done every six months regarding the level of progress in preparing accreditation covering seven accreditation standards, namely: (1) standards 1 vision, mission, goals and objectives and achievement strategies; (2) standards 2 governance and leadership; (3) standards 3 students and graduates; (4) standards 4 human resources; (5) standards 5 curriculum and learning; (6) standards 6 financing, facilities, and infrastructure; and (7) standards 7 research, service, community service, and cooperation.

\section{REFERENCES}

[1] Handoko, H. T. 1986. Management. Yogyakarta: BPFE.

[2] Indonesia Government Regulation Number 19 of 2005 Concerning National Education Standards. 2006. Bandung: Citra Umbara.

[3] Indonesian Law Number 20 of 2003 concerning the National Education System. 2009. Jakarta: Sinar Grafika.

[4] Indrajit, and Djokopranoto. 2006. Modern College Management. Yogyakarta: Penerbit ANDI.

[5] Khairuddin. 2011. Integrated Quality Management in Education. Banda Aceh: Al-Mumtaz Institute.

[6] National Accreditation Board for Higher Education, Book II. 2013. Standards and Procedures of Study Program Accreditation. Jakarta: Ministry of Education and Culture.

[7] Law Number 12 of 2012 on National Education. 2013. Bandung: Citra Umbara.

[8] Law Number 14 of 2005 on Teacher and Lecturer. 2006. Bandung: Citra Umbara.

[9] Riduwan. 2010. Methods and Techniques for Composing Thesis. Bandung: Alfabeta.

[10] Satori, D., and Aan, K. 2010. Qualitative Research Methodology. Bandung: Alfabeta.

[11] Sugiyono. 2013. Combined Research Method. Bandung: Alfabeta.

[12] Sutrisno. E. 2011. Human Resource Management. Jakarta: Kencana Prenada Media Group.

[13] Usman, N. 2012. Management of Quality Improvement of Teachers' Performance: Concept, Theory, and Model. Jakarta: Citapustaka Media Perintis.

[14] Usman, H. 2014. Management: Theory, Practice and Educational Research. Jakarta: PT Bumi Aksara. 